\author{
Sibel Doğan, \\ Ahmet Ünlü*
}

\section{Giant Hidradenoma of the Thigh a 14-Year Old Boy}

\author{
On Dört Yaşındaki Çocuk Hastada Uyluk \\ Yerleşimli Dev Hidradenom Olgusu
}

\section{Abstract}

Hydradenomas, also known as nodular hydradenomas are usually rare seen cutaneous eccrine tumors. They are usually seen on the scalp, trunk and extremities. Hydradenomas occur most commonly in the adulthood. They can reach very large sizes, taking the name of giant hydradenoma which may present with tenderness and change in skin color. The differential diagnoses must include cystic hygroma, soft tissue tumors like fibroma, synovial cell sarcoma, osteochondroma and neuroblastoma metastasis in childhood. Here, a 14-year-old boy is presented with a giant clear cell hydradenoma case on the left thigh. Acoording to the furthest literature we have reached; this is the first case in which the giant clear-cell hydradenoma was reported on the thigh location in childhood.

Keywords: Hidradenoma, thigh, eccrine tumors, benign, neoplasia, childhood

\section{Öz}

Nodüler hidradenom olarak da bilinen hidradenomlar genel olarak nadir görülen kutanöz ekrin deri tümörleridir. Genellikle skalp, gövde ve ekstremitelerde görülürler. Hidradenomlara genellikle erişkin çağda rastlanır. Çok büyük boyutlara ulaşabilirler, hassasiyet ve renk değişikliğine sebep olabilen bu durumda dev hidradenom adını alırlar. Burada 14 yaşındaki bir erkek çocuk hastada uyluk yerleşimi gösteren dev berrak hücreli hidradenom olgusu sunulmaktadır. Literatürde yaptığımız taramalara dayanarak bu sunum uyluk yerleşimli olarak dev berrak hücreli hidradenomun çocukluk çağında bildirildiği ilk olgu olma özelliğindedir.

Ankara Numune Training and Research Hospital, Clinic of Skin and Venereal Diseases, Ankara, Turkey

*Antalya Training and Research Hospital, Clinic of Pediatric Surgery, Antalya, Turkey

\section{Correspondence/} Yazışma Adresi:

Sibel Doğan, Ankara Numune Training and Research Hospital, Clinic of Skin and Venereal Diseases, Ankara, Turkey E-mail: sibel.dogan@hacettepe.edu.tr ORCID ID:

orcid.org/0000-0002-5383-6886 Submitted/Geliş Tarihi: 27.06.2013 Accepted/Kabul Tarihi: 26.03.2014

${ }^{\circledR}$ Copyright 2017 by Turkish Society of Dermatology by Galenos Publishing House.

Anahtar kelimeler: Hidradenom, uyluk, ekrin tümörler, benign, neoplazi, çocukluk çağı

\section{Introduction}

Hidradenomas, also known as nodular hidradenomas are benign relatively common cutaneous eccrine tumors (1). Giant forms of hidradenomas are rarely reported in the literature $(1,2)$. Herein, we report a 14 year old boy with a giant clear cell hidradenoma of the left thigh.

\section{Case Report}

A 14-year-old boy was admitted to our outpatient dermatology clinic for a soft tissue mass on the left inner thigh. The family explained that the mass had started as a bluish-red slightly tender plaque 2 months ago, thereafter it started to get firm and more appreciable. Soon after the mass expanded to its final dimensions, pain had started. The patient had no characteristics on personal medical and family history. On dermatologic examination, a bluish to skin colored soft tissue mass was palpated on the left inner thigh with a multinodular appearance (Figure 1). The regional lymph nodes were not palpated, the rest of the physical examination was normal. The tumor's dimensions were noted as $10 \mathrm{~cm}$ $x 7 \mathrm{~cm} \times 12 \mathrm{~cm}$. According to the clinical examination, differential diagnoses of peadiatric soft tissue tumors including desmoid fibromatosis, fibrosarcoma, liposarcoma, leiomyosarcoma, metastasis of neuroblastoma, vascular hemangioma, cystic hygroma and angiosarcoma were made. A slight possibility of cutaneous adnexal tumours were kept in mind as the lesion was firm but not infiltrative clinically, 
there was a bluish hue and lesion was tender when palpated. In addition, patient's general condition was very good and there were no additional accompanying comorbidities. Because of the abrupt appearance and giant dimensions of the lesion, the patient was consulted with pediatric surgery based on the differential diagnoses. An excisional biopsy was performed with total resection of the tumor (Figure 2). On histopathologic examination, both solid and cystic areas with papillary excrescences were noted, cuboid cells lined the glandular spaces, mitotic figures and necrosis were not observed and a diagnosis of benign hidradenoma was made.

\section{Discussion}

Hidradenomas, also known as nodular hidradenomas, clear cell hidradenoma or acrospiroma are benign relatively common cutaneous eccrine tumors $(1,2)$. The tumor arises from the distal excretory duct of sweat glands (3). They are mainly seen on the scalp, trunk and extremities but also reported to be seen in face, palms, axilla and shoulder (1-4). Hidradenomas occur most common in the adulthood and in women twice as commonly as men (2-5). They generally enlarge slowly, can be solid or cystic clinically. When they reach to large sizes they are referred as giant hidradenomas which may present with tenderness and change in skin color (5-8). Hidradenomas are usually slow growing tumors but as in our case they may show abrupt progression. The differential diagnosis must include cyctic hygroma, soft tissue tumors like fibrosarcoma, synovial cell sarcoma, osteochondroma and
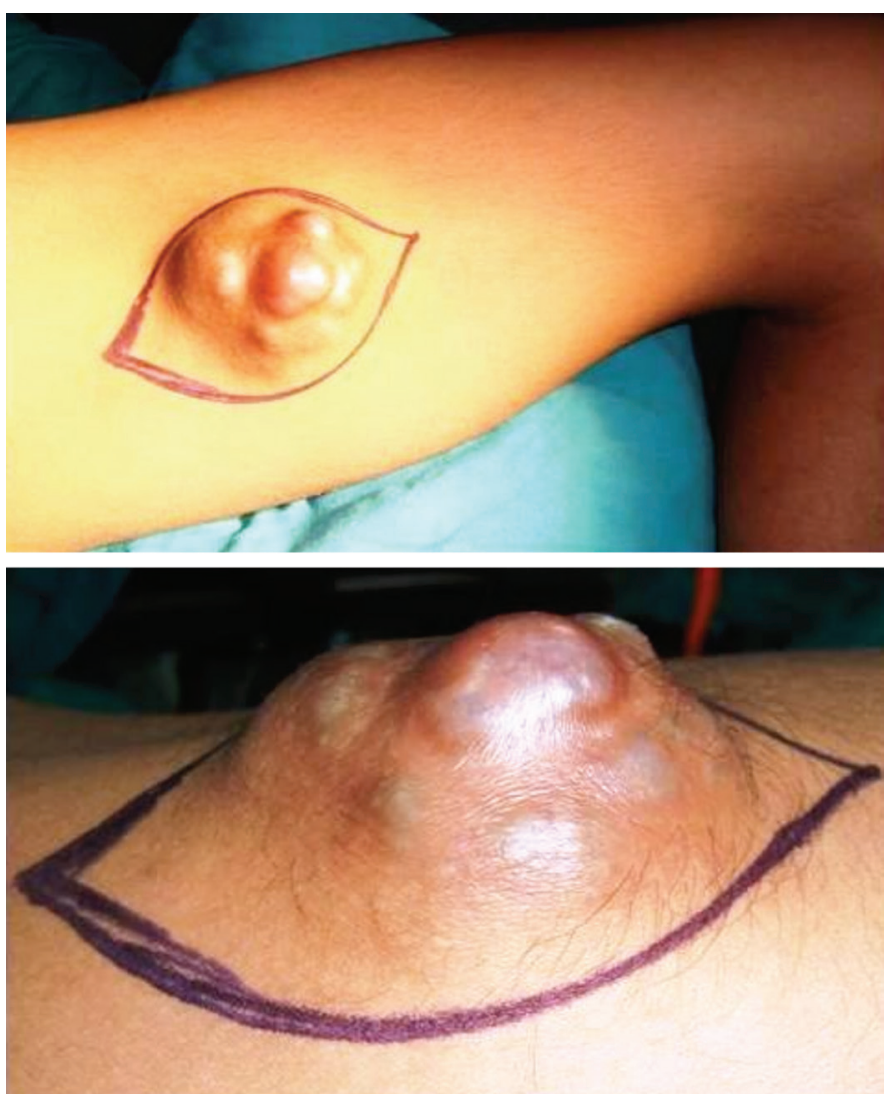

Figure 1. Bluish to skin colored tumor with a multinodular appearance on the left inner thigh neuroblastoma metastasis in childhood $(3,9)$. Histapathology and immunohistochemical staining are helpful in differentiation and final diagnosis $(3,8,9)$. Hidradenomas are characterized by cuboidal or columnar cells lining tubular lumina and they also contain cystic spaces. Recognition of polihedral basophilic cells and glycogen containing pale cells is a strong clue for sweat gland origin of the tumor. Malignant hidradenomas are rarely reported in the literature, in this case nuclear atypia, bizarre mitotic figures, infiltrative patterns, necrosis and invasion may be seen $(1,3,4)$. Follow-up of hidradenomas can be mandatory, as a young girl with a diagnosis of benign hidradenoma progressed to a malignant sweat gland carcinoma with metastasis within a decade in the literature (10).

To our knowledge, our case is the first reported giant hidradenoma located on the thigh in childhood. We find our case appreciable to be presented as it emphasizes how important it is to remember cutaneous adnexal neoplasias as a differential diagnosis in cutaneous giant masses in childhood and the differential diagnoses are highly variable according to the age of the patient in such a case. In our case,
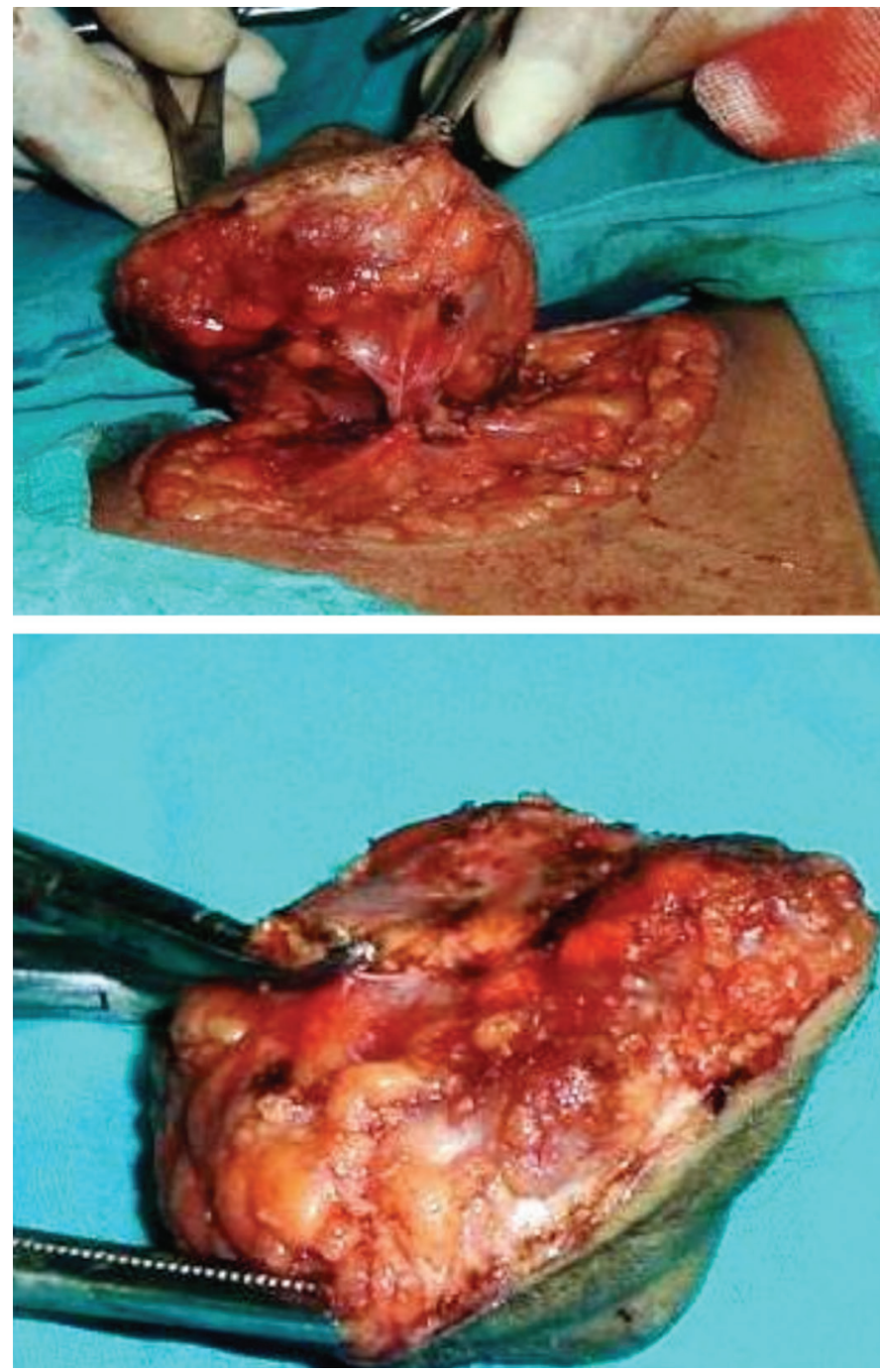

Figure 2. A mass with both cystic and solid components 
excision of the mass was diagnostic and therapeutic hence a recurrence was not observed to a 6 month clinical follow up.

\section{Ethics}

Informed Consent: A consent form was completed by all participants.

Peer-review: Internally peer-reviewed.

\section{Authorship Contributions}

Surgical and Medical Practices: S.D., A.Ü., Concept: S.D., Design: S.D., Data Collection or Processing: S.D., Analysis or Interpretation: S.D., Literature Search: S.D., Writing: S.D.

Conflict of Interest: No confilt of interest was declared by th authors.

Financial Disclosure: The authors declared that this study received no financial support.

\section{References}

1. Tony B, Stephen B, Neil C, et al. Rook's Textbook of Dermatology. 8th ed. Wiley-Blackwell; 2010. p. 3721-2.
2. El Demellawy D, Daya D, Alowami S. Clear cell hidradenoma: an unusual vulvar tumor. Int J Gynecol Pathol 2008;27:457-60.

3. Elder $\mathrm{D}$, Elentisas R, Ragsdale BD. Tumors of the epidermal appendages. In: David E, editor. Lever's Histopathology of the Skin. Philadelphia: LippincottRaven Publishers; 1997. p. 747-804.

4. Cho KE, Son EJ, Kim JA, et al. Clear cell hidradenoma of the axilla: a case report with literature review. Korean J Radiol 2010;11:490-2.

5. Ogilvie JW. Malignant eccrine acrospiroma. A case report. J Bone Joint Surg Am 1982;64:780-2.

6. De Toma G, Plocco M, Nicolanti V, et al. Malignant nodular hidradenoma. A clinical case. Minerva Chir 2000;55:185-7.

7. Toulemonde A, Croue A, Rodien $\mathrm{P}$, et al. Malignant nodular hidradenoma and multiple nodular hidradenomas in a hypogonadic patient. Ann Dermatol Venereol 2006;133:1005-8.

8. Lim SC, Lee MJ, Lee MS, et al. Giant hidradenocarcinoma: a report of malignant transformation from nodular hidradenoma. Pathol Int 1998;48:818-23.

9. Berquist TH, Ehman RL, King BF, et al. Value of MR imaging in differentiating benign from soft tissue masses: Study of 95 lesions. AJR Am J Roentgenol 1990;15:1251-5.

10. Biddlestone LR, McLaren KM, Tidman MJ. Malignant hidradenoma: a case report demonstrating insidious histological and clinical progression. Clin Exp Dermatol 1991;16:474-7. 